\title{
Can returnee managers promote CSR performance? Evidence from China
}

\author{
Wen Wen and Jianbo Song
}

\author{
* Correspondence: \\ songjianbo@rbs.ruc.edu.cn \\ School of Business, Renmin \\ University of China, Beijing, China
}

\begin{abstract}
With growing economic globalization, returnee managers who have obtained education or work experience overseas play a much more crucial role in corporations, especially in emerging economies. Using hand-collected managerial background data from a sample of firms listed on the Shanghai and Shenzhen Stock Exchanges from 2010 to 2014, this paper investigates the impact of returnee managers on corporate social responsibility (CSR) performance. We find that returnee managers can promote CSR performance. Further analyses show that the impact of returnee managers on CSR is more pronounced when managers have a foreign study background compared to managers with foreign work experience. The impact only holds when managers obtained their experience in developed economies. When enterprises face greater information asymmetry, returnee managers are more willing to use CSR as a tool to convey a positive image to stakeholders. CSR can help managers reduce information asymmetry and improve firm value. The results are robust through a series of robustness checks including a propensity score matching (PSM) procedure and a Heckman two-state sample selection model. This paper contributes to growing studies on the economic consequences of returnee managers and advances our understanding of the determinants of CSR at the individual level. The results also have implications for government and enterprises attracting talents with overseas experience.
\end{abstract}

Keywords: Returnee managers, Corporate social responsibility, Upper echelons theory, Stakeholders, Information asymmetry

\section{Introduction}

Corporate Social Responsibility (CSR) refers to the actions of firms that go beyond their own immediate interests, making further contributions to improving the social, ethical, labor and environmental conditions in which they operate (Davis 1973; McWilliams and Siegel 2001). CSR has attracted attention worldwide since the 1990s. Government and non-governmental organizations have launched corporate social responsibility campaigns worldwide by revising laws and regulations, and introducing a series of social responsibility rules and standards. The Chinese government also attaches great importance to CSR. In 2002, the "Guidelines on Corporate Governance of Listed Companies" promulgated by the China Securities Regulatory Commission (CSRC) clearly stipulates that listed firms should respect and safeguard the legitimate rights and interests of stakeholders, and pay attention to corporate social responsibilities while maximizing the interests of shareholders. As well, the promulgated "CSR Standards", the new "Company Law" and "Guiding

(c) The Author(s). 2017 Open Access This article is distributed under the terms of the Creative Commons Attribution 4.0 International License (http://creativecommons.org/licenses/by/4.0/), which permits unrestricted use, distribution, and reproduction in any medium, provided you give appropriate credit to the original author(s) and the source, provide a link to the Creative Commons license, and indicate if changes were made. 
Opinions on Social Responsibility of State-owned Entities" have set out specific requirements and guidance for enterprises to fulfill their social responsibilities. Many firms have sought to enhance the scope and depth of their CSR accordingly and commit to a more sustainable future spurred by laws and regulations.

CSR performance in Chinese firms has improved in recent years, but is still far from satisfactory. According to an official CSR evaluation report released by Hexun.com, ${ }^{1}$ the overall average CSR score of Chinese listed companies is only 29, far below the cutoff score of 60 . Only 75 companies have received passing scores, comprising only $2.65 \%$ of the total listed companies in both the Shanghai and Shenzhen stock exchanges. Although the number of voluntary disclosures of CSR evaluation reports has been increasing year by year, a large number of reports hold back negative information and "clone" previous years' reports. In addition, corporate philanthropy can become a cover-up used by companies to prevent reputation loss and is not a consistent practice of companies (Gao et al. 2012). Due to the current institutional background and regulatory policies, how to improve CSR performance in China is worth in-depth study and discussion.

Previous literature reveals that institutional and organizational level factors have a great impact on CSR, but limited attention has been paid to the individual level (Aguinis and Glavas 2012). CSR investments require decisions by management. Commitment from supervisors to CSR is a key predictor of CSR performance (Greening and Gray 1994; Muller and Kolk 2010; Ramus and Steger 2000; Weaver et al. 1999a, 1999b). Little attention has been paid to whether returnee managers can play a different role in CSR performance.

In China, managerial foreign experience is an important and beneficial characteristic for firm managers. China is still an emerging economy despite rapid economic development since the 1970s. Chinese students go abroad and study in the universities of developed countries. ${ }^{2}$ Some of them work in foreign enterprises after graduation. Those individuals with foreign study or work experience are regarded as high-level talents. They return to their home country with advanced knowledge and new ideas. Compared with China's enormous population, these returnee managers are still scarce. Due to this reason, the Chinese government has released a batch of policies to attract these talents to return to work in China, ${ }^{3}$ providing them with superior benefits. However, whether these individuals fulfill their expected role is still an empirical question.

In this paper, we empirically explore the impact of returnee managers on CSR based on manually collected managerial background data over the period of 2010 to 2014 . We find that these returnee managers have a positive association with CSR. We have conducted a series of robustness checks including propensity score matching (PSM), Heckman two-stage sample selection, alternative measure of CSR, and alternative definition of returnee managers and find that the results are robust. Further analyses show that this association is more pronounced if managers have foreign study experience compared with foreign career work experience. In addition, when firms face greater information asymmetry, returnee managers are more willing to use CSR as a tool to convey a positive image to outsiders. Further tests show that CSR can help managers reduce information asymmetry and improve firm value.

Our study contributes to the literature in the following ways. First, our paper is one of the few to test the effect of managerial foreign experience on CSR, which enriches the literature on the determinants of CSR performance. Aguinis and Glavas (2012) 
summarize that most CSR papers focus on institutional and organizational levels of analysis. Only a small minority of CSR research has paid attention to the individual level. This study answers their call for more research to examine CSR at the individual level. Our study provides direct evidence that individuals' foreign background is a significant factor in determining firms' CSR investment.

Second, our paper enriches the small but growing number of studies on the economic influences of returnee managers. Little empirical evidence has been provided to demonstrate the relationship between returnee managers and corporate outcomes although this question is both interesting and important. Giannetti et al. (2015) explore the impact of directors with foreign experience on firm performance with data from Chinese listed firms from 1999 to 2009. They find that the performance of firms increases after they employ directors with foreign experience. Miletkov et al. (Miletkov et al. 2017) use a large sample of non-U.S. firms and find that there is a positive association between foreign independent directors and firm performance. They also find that this relationship is more pronounced in countries where legal institutions are relatively weak. Our study focuses on the impact of returnee managers on CSR, which contributes to the existing literature by providing evidence of a new economic consequence of CSR.

Finally, our findings have important implications for both government and companies. Since the 1990s, the Chinese government has released a number of policies to attract talents with foreign study and work experience to work in Chinese mainland (Zweig 2006; Giannetti et al. 2015). Economic globalization, together with the internationalization of Chinese enterprises, pushes the returnee manager issue even further to the forefront. Our findings are consistent with the notion that the presence of returnee managers has significance for corporate strategic decisions in terms of CSR, which supports the Chinese government's recent efforts to recruit returnee managers.

The rest of the paper proceeds as follows. The following section reviews related studies and develops our hypothesis. Section 3 presents the research design and sample distribution. Section 4 provides empirical results and section 5 presents several robustness checks. Section 6 conducts further studies and section 7 concludes the paper.

\section{Related studies and Hypothesis development}

Commitment from managers is crucial for CSR performance (Greening and Gray 1994; Muller and Kolk 2010; Ramus and Steger 2000; Weaver et al. 1999a, 1999b). Managers have a significant impact on the establishment and maintenance of their corporate image. Hanniffa et al. (2005) find that the ethnicity and education background of a board of directors influences the voluntary disclosure of CSR. Han et al. (2012) find that interlocking directors are information intermediates among corporations and can affect CSR disclosure by imitating each other. Wang et al. (2015) demonstrate that a CEO's religious beliefs have a positive effect on corporate philanthropy.

With the progress of economic globalization, returnee managers gradually attract public attention and have become a non-negligible group in the Chinese capital markets. These individuals bring back new ideas and advanced knowledge and act as cross-border intermediaries. Overseas study and work experience are important opportunities for managers and affect their cognitive abilities and values. We expect that this experience will ultimately affect their firms' business decisions. However, existing research has not fully explored the impact of returnee managers on corporate 
governance. To the best of our knowledge, no literature tests managerial foreign experience on firms' CSR performance.

Upper echelons theory suggests that organizational outcomes (e.g., strategic choices and performance levels) can be predicted by managerial background characteristics (Hambrick and Mason 1984). Returnee managers can promote CSR according to upper echelons theory. CSR varies considerably among developed countries and emerging economies. Many believe CSR is a western invention. Firms in developed countries have more established social values and face stricter institutional pressures to fulfill their social responsibilities (Campbell 2007). This may be reflected in vast ranges of applications such as employment protection, environmental responsibilities, product quality, and so on. However, the situation is quite different in emerging economies such as China, where schools still lack systematic CSR education and managers are still weak in their awareness of CSR (Yi 2011). According to upper echelon theory, managers' educational background and career experiences have a significant effect on the types of decisions managers make. In terms of CSR, returnee managers have long been educated in overseas culture and have developed a strong sense of social responsibility. When facing strategic choices, managers can use their own cognitive based values which can actively promote a commitment to social responsibility and lead firms to engage in better CSR. Engaging in study or work overseas may be one of the biggest decisions in one's life, especially for people in emerging countries such as China. People can be exposed to dramatically different cultures and lifestyles during this period, and the overseas experience could result in a change in one's cognitive awareness of CSR and eventually affect their decision-making regarding CSR.

Although most CSR literature covers the benefits side of CSR, there is still a strand of literature that focuses on the cost side of CSR. Barnea and Rubin (2010) suggest that CSR engagement is a principal-agent relationship between managers and shareholders. Overconfident managers tend to over-invest in CSR in order to obtain private benefits, such as a positive reputation from publicity. Thus CSR investment is sometimes value-destroying to shareholders when the agency problem is serious. Returnee managers are regarded as highly skilled talents in emerging economies such as China. They may become superstars in corporations and capital markets. As well, society has higher expectations for these returnee managers, hoping they can bring about benefits not only to the corporations, but also to other stakeholders. Therefore, returnee managers may be more willing to engage in CSR activities to build their reputations, and thus can promote CSR performance.

In summary, the above discussions lead us to the following hypothesis:

Hypothesis: Returnee managers can promote corporate social responsibility, all else being equal.

\section{Research design}

\section{Sample selection and Data sources}

We begin with all the Chinese listed companies on the SHSE and SZSE from 2010 to 2014. We choose 2010 as the beginning year of our sample period because Hexun.com started to release its evaluation system of listed companies' CSR performance in 2010. We exclude financial firms (e.g., insurance companies and banks) because of the uniqueness 
of their asset structure and earnings generating process. After deleting observations with missing data, we finally get 8052 observations.

CSR score and CSR rating data are downloaded from Hexun.com. Managerial foreign experience data is manually collected from biographic information from annual reports downloaded from the official websites of the SHSE and SZSE (www.sse.com.cn and www.szse.cn, respectively). We double-checked the data with Sina (http://finance.sina.com.cn) and Baidu (http://baike.baidu.com), and the websites of each individual listed company. In this way, we obtain information on the academic degrees managers obtained abroad, managerial work experience and the country where the managers studied or worked. The data of institutional investors is obtained from the WIND system, other financial and corporate governance data used in this study are obtained from China Stock Market Accounting Research (CSMAR) system. The data are crosschecked for consistency.

\section{Measurement of corporate social responsibility}

Our test variable is CSR performance. Following Jia and Liu (2014), we use the data of CSR evaluation system of listed companies released by Hexun.com. ${ }^{4}$ We use two variables, CSR_Score and CSR_Rate to proxy for CSR performance. Higher scores and a better social responsibility rating both indicate superior performance of a firm's CSR. In contrast to other CSR evaluation methods which are only based on firms' annual CSR reports, Hexun.com's CSR evaluation system is based on both annual reports and CSR reports. Even if the listed company does not disclose a CSR report, the evaluation system can still assess the relevant content of the annual reports on the implementation of corporate social responsibility. With a relatively limited number of companies voluntarily disclosing CSR reports at this stage in China, ${ }^{5}$ we believe Hexun.com's evaluation method is more comprehensive.

\section{Measurement of returnee managers}

Our test variable is returnee managers. Following Giannetti et al. (2015), we consider that a manager has foreign experience if he or she has studied or worked outside Chinese mainland. We do not regard managers who worked for a foreign branch of a Chinese company or those employed by a Chinese branch of a foreign company as having foreign experience, ensuring that this measure can capture actual exposure to a foreign environment.

We adopt two variables to gauge returnee managers: (1) Returnee (0/1), a dummy variable which equals 1 if firm $i$ has at least one manager who has a previous study or work experience overseas in year $t$ and 0 otherwise. Considering that CSR investment is part of corporate management decisions, we adopt a narrow definition of managers (i.e., $\mathrm{CEO}$, vice $\mathrm{CEO}, \mathrm{CFO}, \mathrm{COO}$ and other top executives). The board of directors is not considered in this paper since directors play a relatively small monitoring and consulting role in corporations. (2) Returnee number, the number of managers who have a foreign study or work experience in year $t$. In further analyses, we distinguish the type of returnee managers into basically two categories: (1) Returnee study (0/1), a dummy variable which equals 1 if firm $i$ has at least one manager who has previous study experience overseas in year $t$ and 0 otherwise. (2) Returnee work (0/1), a dummy 
variable which equals 1 if firm $i$ has at least one manager who has previous work experience overseas in year $t$ and 0 otherwise. In addition, we further clarify the countries where managers obtained their foreign experience. Specifically, we define two variables: (1) Returnee developed (0/1) is a dummy variable which equals 1 if firm $i$ has at least one manager who obtained his overseas experience from at least one developed economy $^{6}$ in year $t$ and 0 otherwise. (2) Returnee number is the number of managers who obtained experience from advanced economies.

Models

We employ an OLS model to examine the influence of managerial foreign experience on CSR. We cluster standard errors by firm to control for cross-sectional correlation. We estimate the following regression model:

$$
\operatorname{CSR}_{i, t}+\beta_{0}+\beta_{1} \text { Returnee }_{i, t}+\beta_{2} \text { Controls }_{i, t}+\text { Industry }+ \text { Year }+\varepsilon,
$$

where $\beta_{i}$ represents regression coefficients, $\varepsilon$ is an error term. CSR is the dependent variable. We adopt two variables to measure corporate social responsibility, namely CSR_Score and CSR_Rate. CSR score and rate are both released by Hexun.com for firm $i$ in year $t$, the larger CSR_Score and higher CSR_Rate represent better CSR performance. Returnee is the test variable, measured by whether firm $i$ has returnee managers and the number of returnee managers in year $t$. Based on previous CSR literature, we include the following control variables in the analysis.

\section{State control (0/1)}

State-owned enterprises take on more social and political responsibilities from the government. In this study, state control is defined as a dummy variable equals 1 if the firm is a state-owned entity (either controlled by the central Chinese government or the local government) and 0 otherwise.

\section{Board independence}

Independent directors have the privilege to provide a voice for small shareholders when their interests are adversely affected. Board independence is measured as the proportion of independent directors to the total number of directors on a board.

\section{Power balance}

Power balance represents the relative balancing ability of the other shareholders to the largest shareholder. Large shareholders can obtain private benefits at the expense of other shareholders. When the balancing power is stronger, firms are more likely to engage in CSR activities. Power balance is measured as the ratio of the number of shares held by the largest shareholder divided by the sum of the number of shares held by the second to the fifth largest shareholders.

\section{Duality (0/1)}

If the CEO and chairman is the same person, the CEO has more power and receives less monitoring from the board of directors. Thus, a duality CEO may have a lower propensity to engage in CSR and try to maximize his own performance. Duality is defined as a dummy variable that equals 1 if the chairman and CEO is the same person and 0 otherwise.

\section{Managerial ownership}

CSR engagement is a principle-agent relation between managers and shareholders (Barnea and Rubin 2010). Ownership structure plays an important role in the amount 
of CSR expenditure. Managers tend to maximize their own benefits according to agency theory. Since CSR is costly for firms to some extent, managers need to balance their firm's financial performance and CSR performance. When managers have greater ownership, they tend to be more short-sighted and are less inclined to engage in CSR (Wang et al. 2014). Managerial ownership is measured as the number of shares held by management divided by the total shares in issue.

Institutional ownership

Different types of shareholder ownership reflect different investor preferences. Institutional investors pay more attention to the sustainability and long-term prospects of business than other types of shareholders (Oh et al. 2011). CSR strategies can enhance the competitiveness of firms, build better government and community relationships and increase the economic value of firms. Thus, institutional investors can promote firms to engage in CSR. Institutional ownership is measured as the number of shares held by institutional investors divided by the total shares in issue.

\section{Firm age}

Firm age is highly correlated with CSR engagement (Harjoto and Jo 2011), so we control this variable in the model. Firm age is equal to the difference of fiscal year $t$ minus the year the firm was established.

Size

Size reflects the complexity of a firm's resources and stakeholder relationships. Larger firms are more capable of engaging in environmental protection activities, employment benefits, etc. Size is measured as the natural logarithm of the book value of total assets.

\section{Return on assets}

According to slack resource theory, firms in relatively weak financial condition are less likely to invest in corporate social responsibility than firms with strong financial performance (Waddock and Graves 2015). ROA is equal to net income divided by total assets.

\section{Leverage}

Leverage reflects a firm's capital structure and is an important index for a firm's financial distress. Leverage may increase business operating risk and interest burdens. When firms have high-interest payments, their ability to invest in CSR is limited. Thus we predict that highly leveraged firms are less likely to perform well in CSR. Leverage is measured as the book value of total debts divided by the book value of total assets.

Moreover, we add industry dummies and year dummies to control for the industrial fixed effect and dynamic changes in the macroeconomic environment. All continuous variables are winsorized at $1 \%$ at both tails to mitigate the undue influence of extreme values. The definition of all main variables is presented in the Appendix A.

\section{Empirical results}

Descriptive statistics

Table 1 presents summary statistics of main variables used in our regression analysis. Panel A is descriptive statistics for CSR. The average CSR_Score is only 27.505, far below the pass level of 60. The mean and median value of CSR_Rate is 2.311 and 2.000, which demonstrates that CSR performance in China still needs improvement.

Table 1 Panel B shows the descriptive statistics of returnee manager variables. On average, at least $12.3 \%$ of total observations have at least one returnee manager with 
Table 1 Descriptive Statistics

\begin{tabular}{|c|c|c|c|c|c|c|c|c|}
\hline Variables & $\mathrm{N}$ & Mean & Std. & Median & Min & P25 & P75 & Max \\
\hline \multicolumn{9}{|l|}{ Panel A: Variables of CSR } \\
\hline CSR_Score & 9519 & 27.505 & 18.680 & 21.390 & -13.570 & 16.610 & 30.180 & 85.770 \\
\hline CSR_Rate & 9519 & 2.311 & 0.686 & 2.000 & 1.000 & 2.000 & 2.000 & 5.000 \\
\hline RKS_Score & 2414 & 36.136 & 12.165 & 33.090 & 11.690 & 28.000 & 40.440 & 87.950 \\
\hline RKS_Rate & 2391 & 6.406 & 2.973 & 5.000 & 1.000 & 4.000 & 8.000 & 18.000 \\
\hline \multicolumn{9}{|c|}{ Panel B: Variables of returnee managers } \\
\hline Returnee (0/1) & 9519 & 0.123 & 0.329 & 0.000 & 0.000 & 0.000 & 0.000 & 1.000 \\
\hline Returnee number & 9519 & 0.176 & 0.586 & 0.000 & 0.000 & 0.000 & 0.000 & 10.000 \\
\hline Returnee work & 9519 & 0.050 & 0.218 & 0.000 & 0.000 & 0.000 & 0.000 & 1.000 \\
\hline Returnee study & 9519 & 0.106 & 0.307 & 0.000 & 0.000 & 0.000 & 0.000 & 1.000 \\
\hline Returnee developed (0/1) & 9519 & 0.122 & 0.328 & 0.000 & 0.000 & 0.000 & 0.000 & 1.000 \\
\hline Returnee number developed & 9519 & 0.172 & 0.574 & 0.000 & 0.000 & 0.000 & 0.000 & 10.000 \\
\hline \multicolumn{9}{|l|}{ Panel C: Other variables } \\
\hline State control $(0 / 1)$ & 9519 & 0.032 & 0.176 & 0.000 & 0.000 & 0.000 & 0.000 & 1.000 \\
\hline Board independence & 9519 & 0.366 & 0.043 & 0.333 & 0.125 & 0.333 & 0.400 & 0.444 \\
\hline Power balance & 9519 & 5.446 & 7.530 & 2.360 & 0.398 & 1.174 & 6.017 & 37.377 \\
\hline Duality (0/1) & 9519 & 0.214 & 0.410 & 0.000 & 0.000 & 0.000 & 0.000 & 1.000 \\
\hline Managerial ownership & 9519 & 0.083 & 0.163 & 0.000 & 0.000 & 0.000 & 0.045 & 0.519 \\
\hline Institutional ownership & 9519 & 0.245 & 0.229 & 0.192 & 0.000 & 0.009 & 0.456 & 0.618 \\
\hline Firm age & 9519 & 14.626 & 5.296 & 15.000 & 1.000 & 11.000 & 19.000 & 34.000 \\
\hline Size & 9519 & 21.721 & 1.093 & 21.661 & 18.724 & 20.976 & 22.468 & 23.602 \\
\hline$R O A$ & 9519 & 0.041 & 0.065 & 0.041 & -0.389 & 0.015 & 0.075 & 0.135 \\
\hline Leverage & 9519 & 0.424 & 0.222 & 0.421 & 0.028 & 0.246 & 0.600 & 0.830 \\
\hline
\end{tabular}

foreign experience though the number of returnee managers can be as high as 10 . The means of Returnee work (0/1) and Returnee study (0/1) are 0.050 and 0.106, demonstrating that $5.0 \%$ of firms have returnee managers with foreign work experience while $10.6 \%$ of returnee managers have foreign study experience. The mean value of Returnee developed (0/1) is 0.122 , demonstrating that nearly $99.2 \%(0.122 / 0.123)$ of returnee managers gained their overseas experience in developed economies.

Table 1 Panel $C$ provides summary statistics of control variables. On average, firms in our sample have a State control (0/1) of 0.032, Board independence of 0.366, Power balance of 5.446, Duality (0/1) of 0.214. Managerial ownership of 0.083 and Institutional ownership of 0.245 , Firm age of 14.626, Size of 21.721, ROA of 0.041, and Leverage of 0.424 . These firm characteristics are similar to those reported in previous studies.

\section{Correlation analysis}

Table 2 presents Pearson and Spearman correlation coefficients between variables. CSR_Score is significantly and positively correlated with Returnee (0/1), which is consistent with our hypothesis that Returnee managers have a positive effect on CSR. The results also show that all the correlations between independent variables are relatively low. To further test the potential of multicollinearity, we compute the variance inflation factor (VIF) for dependent variables. The maximum value is 1.640 , well below the rule 


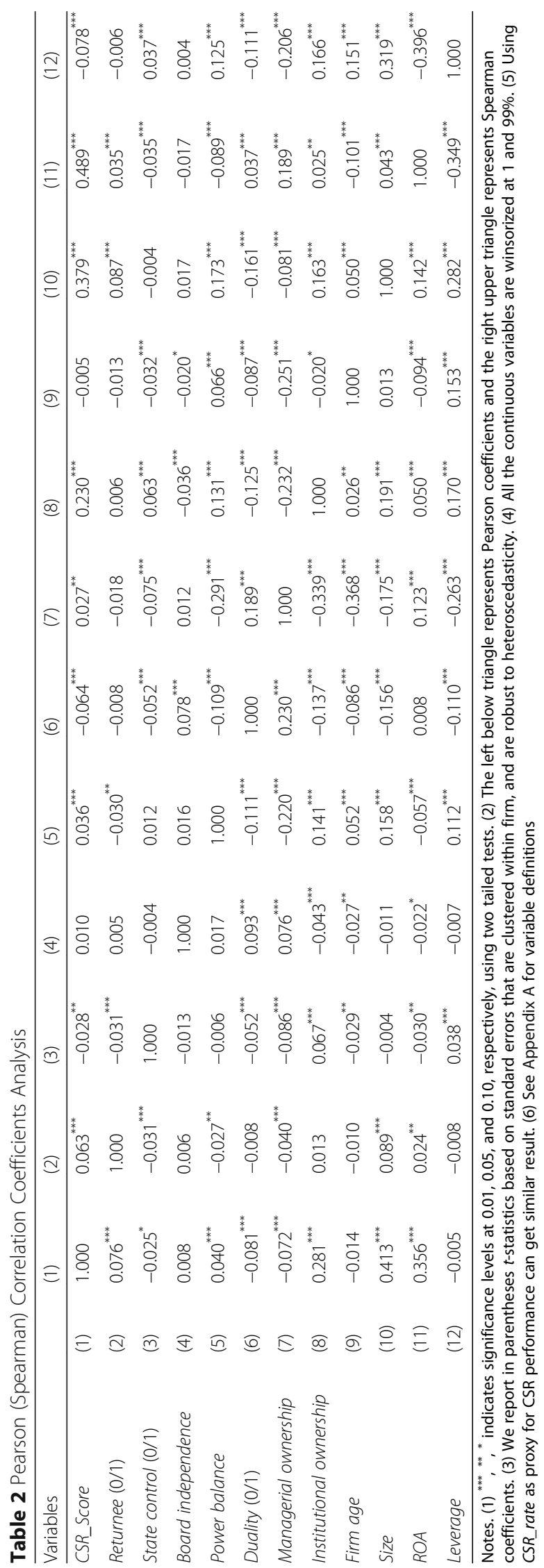


of thumb cutoff of 10 for regression models (Kennedy 1988). Therefore, we think that multicollinearity may not be a significant issue in our study.

\section{Multivariate results}

The multivariate results are included in Table 3. These models are derived from two measures of CSR. The test variables Returnee (0/1), and Returnee number are both significant at the $1 \%$ level, indicating a positive and significant effect of the returnee managers on CSR performance.

Table 3 Regressions of Managerial Foreign Experience and CSR

\begin{tabular}{|c|c|c|c|c|}
\hline & \multicolumn{2}{|c|}{$Y=C S R \_$Score $i, t$} & \multicolumn{2}{|c|}{$Y=C S R \_$Rate $_{i, t}$} \\
\hline & (1) & $(2)$ & (3) & (4) \\
\hline \multirow[t]{2}{*}{ Returnee $(0 / 1)_{i, t}$} & $1.990^{* *}$ & & $0.091^{* * *}$ & \\
\hline & $(2.43)$ & & $(2.77)$ & \\
\hline \multirow[t]{2}{*}{ Returnee number ${ }_{i, t}$} & & $1.443^{* * *}$ & & $0.064^{* * *}$ \\
\hline & & $(2.97)$ & & $(3.14)$ \\
\hline \multirow[t]{2}{*}{ State control $(0 / 1)$ i,t } & $-2.320^{*}$ & $-2.306^{*}$ & $-0.090^{*}$ & $-0.089^{*}$ \\
\hline & $(-1.75)$ & $(-1.74)$ & $(-1.85)$ & $(-1.84)$ \\
\hline \multirow[t]{2}{*}{ Board Independence $_{i, t}$} & $10.805^{*}$ & $11.009^{*}$ & 0.371 & $0.381^{*}$ \\
\hline & $(1.86)$ & $(1.90)$ & $(1.63)$ & $(1.67)$ \\
\hline \multirow[t]{2}{*}{ Power balance $i, t$} & $-0.068^{*}$ & $-0.068^{*}$ & $-0.003^{* *}$ & $-0.003^{* *}$ \\
\hline & $(-1.81)$ & $(-1.80)$ & $(-2.47)$ & $(-2.48)$ \\
\hline \multirow[t]{2}{*}{ Duality $(0 / 1)_{i, t}$} & -0.700 & -0.695 & -0.025 & -0.025 \\
\hline & $(-1.23)$ & $(-1.22)$ & $(-1.14)$ & $(-1.14)$ \\
\hline \multirow[t]{2}{*}{ Managerial ownership i,t } & 1.350 & 1.447 & -0.035 & -0.031 \\
\hline & $(0.78)$ & $(0.83)$ & $(-0.52)$ & $(-0.46)$ \\
\hline \multirow[t]{2}{*}{ Institutional ownership $i, t$} & $12.546^{* * *}$ & $12.597^{* * *}$ & $0.452^{* * *}$ & $0.454^{* * *}$ \\
\hline & $(8.71)$ & $(8.76)$ & (7.99) & $(8.05)$ \\
\hline \multirow[t]{2}{*}{ Firm age $_{i, t}$} & 0.060 & 0.056 & 0.002 & 0.002 \\
\hline & $(1.02)$ & $(0.96)$ & $(0.98)$ & $(0.91)$ \\
\hline \multirow[t]{2}{*}{ Size $_{i, t}$} & $6.373^{* * *}$ & $6.322^{* * *}$ & $0.206^{* * *}$ & $0.204^{* * *}$ \\
\hline & $(23.24)$ & $(22.93)$ & $(19.47)$ & $(19.17)$ \\
\hline \multirow[t]{2}{*}{$R O A_{i, t}$} & $76.648^{* * * *}$ & $76.680^{* * *}$ & $1.585^{* * *}$ & $1.586^{* * *}$ \\
\hline & $(19.43)$ & $(19.43)$ & $(11.23)$ & $(11.25)$ \\
\hline \multirow[t]{2}{*}{ Leverage $_{i, t}$} & $-5.067^{* * *}$ & $-5.038^{* * *}$ & $-0.093^{* *}$ & $-0.092^{* *}$ \\
\hline & $(-4.02)$ & $(-4.00)$ & $(-2.04)$ & $(-2.01)$ \\
\hline \multirow[t]{2}{*}{ Intercept } & $-123.909^{* * *}$ & $-122.841^{* * *}$ & $-2.622^{* * *}$ & $-2.575^{* * *}$ \\
\hline & $(-19.06)$ & $(-18.84)$ & $(-10.34)$ & $(-10.13)$ \\
\hline Year & Yes & Yes & Yes & Yes \\
\hline Industry & Yes & Yes & Yes & Yes \\
\hline Observations & 9519 & 9519 & 9519 & 9519 \\
\hline Adjusted $R$-squared & 0.34 & 0.34 & 0.23 & 0.23 \\
\hline
\end{tabular}

Note: $(1){ }^{* * *},{ }^{* *},{ }^{*}$ indicates significance levels at $0.01,0.05$, and 0.10 , respectively, using two tailed tests. (2) We report in parentheses $t$-statistics based on standard errors that are clustered within firm, and are robust to heteroscedasticity. (3) All the continuous variables are winsorized at 1 and 99\%. (4) See Appendix A for variable definitions 
The coefficients of the control variables are generally consistent with prior literature (e.g., Khan et al. 2013). For corporate governance variables, CSR_Score (CSR_Rate) is negatively and significantly related to State control $(0 / 1)$, demonstrating that state-owned entities have a relative lower CSR performance than non state-owned entities. Board independence is positively significant, which shows that independent directors play a positive role in CSR performance. The coefficient of Power balance is significantly negative, showing that the willingness to practice CSR is lower when ownership concentration is higher. Institutional ownership has a positive effect on CSR, suggesting that institutional investors have longer investment horizons and pay much more attention to firms' sustainability. Size and ROA are both positively significant at the $1 \%$ level, which is consistent with the notion that larger and profitable companies are more capable of fulfilling social responsibilities. Leverage is negatively correlated with CSR, indicating that debt pressure can weaken companies' CSR performance.

\section{Robustness checks}

We conduct a series of additional tests to ensure the robustness of our results, including propensity score matching, Heckman two-stage sample selection method, alternative measure of CSR, and alternative definition of returnee managers.

\section{Propensity score matching}

The hypothesis to be tested is that CSR is a function of managerial foreign experience. However, the results will be difficult to interpret when there is an endogeneity problem. For example, it might be possible that firms with better CSR performance are more attractive to returnee managers. We address the endogeneity problem by adopting propensity score matching (PSM). The primary advantage of using the PSM method is that we can compare firms with returnee managers to a control sample of observations with similar observable dimensions but without returnee managers. In this way, we can clearly attribute any observed effects to the hiring of returnee managers itself.

We identify treatment and control firms based on whether the firm hires returnee managers or not. To make our control firms comparable to the treatment firms, we establish a propensity-score-matched benchmark sample that has the same characteristics as the treatment sample. We construct this benchmark sample by matching each treatment firm to one control firm using the PSM approach. Specifically, we first estimate a Probit model to estimate the propensity of hiring returnee managers. Model (2) represents the specification of the Probit model. In agreement with previous literature (e.g., Giannetti et al. 2015), we add the following determinants of hiring returnee managers: State control (0/1) (a dummy variable which equals 1 if the firm is a state-owned entity and 0 otherwise), Top1 (the proportion of ownership by the largest shareholder), Board size (the number of directors in a board), Managerial ownership (the percentage of common stock owned by managers at each accounting year), Institutional ownership (the percentage of common stock owned by institutional investors at each accounting year), Firm age (the difference of fiscal year $t$ minus the year the firm was established), Size (the natural logarithm of the book value of total assets), Leverage (the book value of total debts divided by the book value of total assets), ROA (net income divided by total assets), Growth (the increased percentage of sales growth in year $t$ ), industry, and year. 


$$
\begin{aligned}
& \text { Returnee }(0 / 1)_{i, t}=\beta_{0}+\beta_{1} \text { State control }(0 / 1)_{i, t}+\beta_{2} \text { Top } 1_{i, t} \\
& +\beta_{3} \text { Board size }_{i, t} \\
& +\beta_{4} \text { Managerial ownership } \\
& +\beta_{5} \text { Institutional ownership } \\
& +\beta_{6} \text { Firm age }_{i, t}+\beta_{7} \text { Size }_{i, t}+\beta_{8} \text { Leverage }_{i, t} \\
& +\beta_{9} R O A_{i, t} \\
& +\beta_{10} \text { Growth }_{i, t}+\beta_{11} \text { Mean }_{\text {Returnee }_{i, t}}+\text { Industry }+ \text { Year } \\
& +\varepsilon_{2} \text {, }
\end{aligned}
$$

where $\beta_{0}$ represents intercept, $\beta_{i}$ represents regression coefficients, $\varepsilon_{2}$ is an error term. The dependent variable Returnee (0/1) is a dummy variable which equals 1 if the firm has at least one returnee manager with foreign experience, otherwise 0 . We compare firms with returnee managers (treatment group) to a sample of control firms without returnee managers (control group) matched with the propensity to hire returnee managers. For each firm in the treatment group, we select one firm in the control group with the closest propensity score, and both these firms constitute the propensity-score matched control sample. PSM should limit the maximum distance between propensity scores with $3.0 \%$ so that not all firms can be matched successfully (Lawrence et al. 2011). Finally, there are 1124 pairs of observations successfully matched. We merged them with the full sample and get 2248 observations as our PSM sample. To further ensure the efficacy of our propensity matching, we conduct a covariate balance analysis (pstest) on the mean difference in the covariates used in the Probit model between the treatment group and control group and present the results in Table 4. The results show that the differences between the treatment group and control group are small across all variables. Thus, our propensity score matching is highly successful.

We re-estimate model (1) using the matched sample and the results are reported in Table 5. The results show that Returnee (0/1), Returnee number are both positively associated with CSR measures, suggesting that returnee managers promote CSR performance after controlling for potential endogeneity.

Table 4 Results of Covariate Balance Checks

\begin{tabular}{llll}
\hline & Means & & Control sample \\
\cline { 2 - 4 } & Test sample & 0.022 & -0.14 \\
\hline State control $_{i, t}$ & 0.021 & 0.359 & -0.15 \\
Top $_{i, t}$ & 0.358 & 9.023 & -0.13 \\
Board size $_{i, t}$ & 9.013 & 0.365 & 1.01 \\
Managerial ownership $_{i, t}$ & 0.367 & 0.059 & 0.68 \\
Institutional ownership $_{i, t}$ & 0.063 & 0.250 & 0.72 \\
Board independence $_{i, t}$ & 0.258 & 14.803 & -0.63 \\
Firm age $_{i, t}$ & 14.666 & 21.888 & 1.58 \\
Size $_{i, t}$ & 21.962 & 0.156 & 0.84 \\
Leverage $_{i, t}$ & 0.161 & 0.047 & -0.99 \\
ROA $_{i, t}$ & 0.044 & -0.356 & -0.40 \\
Growth $_{i, t}$ & -0.411 & &
\end{tabular}

Notes. (1) This table shows the covariate balance checks (pstest) on the main differences between test sample (firms having returnee managers) and control sample (firms without returnee managers) using PSM approach. (2) All the variables are one-year lagged and the definition of variables are presented in Appendix A 
Table 5 Regression Results of Propensity Score Matching

\begin{tabular}{|c|c|c|c|c|}
\hline & \multicolumn{2}{|c|}{$Y=C S R \_$Score $e_{i, t}$} & \multicolumn{2}{|c|}{$Y=C S R \_$Rate ${ }_{i, t}$} \\
\hline & (1) & (2) & (4) & (5) \\
\hline \multirow[t]{2}{*}{ Returnee $(0 / 1)$ i,t } & 1.274 & & $0.054^{*}$ & \\
\hline & $(1.56)$ & & $(1.66)$ & \\
\hline \multirow[t]{2}{*}{ Returnee number i,t } & & $0.862^{* *}$ & & $0.035^{* *}$ \\
\hline & & $(2.53)$ & & $(2.48)$ \\
\hline \multirow[t]{2}{*}{ State control $(0 / 1)_{i, t}$} & 1.116 & -0.329 & 0.014 & 0.000 \\
\hline & $(0.39)$ & $(-0.14)$ & $(0.12)$ & $(0.00)$ \\
\hline \multirow[t]{2}{*}{ Board Independence $_{i, t}$} & 3.047 & 12.268 & 0.131 & 0.526 \\
\hline & $(0.31)$ & $(1.52)$ & $(0.33)$ & $(1.59)$ \\
\hline \multirow[t]{2}{*}{ Power balance $i, t$} & -0.052 & -0.005 & -0.002 & -0.001 \\
\hline & $(-0.91)$ & $(-0.11)$ & $(-0.91)$ & $(-0.59)$ \\
\hline \multirow[t]{2}{*}{ Duality $(0 / 1) i, t$} & -0.042 & $-1.600^{*}$ & -0.012 & -0.056 \\
\hline & $(-0.04)$ & $(-1.79)$ & $(-0.27)$ & $(-1.53)$ \\
\hline \multirow[t]{2}{*}{ Managerial ownership $_{i, t}$} & 1.424 & -0.431 & -0.050 & -0.088 \\
\hline & $(0.39)$ & $(-0.15)$ & $(-0.33)$ & $(-0.74)$ \\
\hline \multirow[t]{2}{*}{ Institutional ownership $i, t$} & $10.648^{* * *}$ & $14.763^{* * *}$ & $0.354^{* * *}$ & $0.547^{* * *}$ \\
\hline & $(4.87)$ & $(7.42)$ & $(4.03)$ & $(6.70)$ \\
\hline \multirow[t]{2}{*}{ Firm age ${ }_{i, t}$} & -0.002 & 0.041 & 0.000 & 0.002 \\
\hline & $(-0.02)$ & $(0.55)$ & $(0.08)$ & $(0.50)$ \\
\hline \multirow[t]{2}{*}{ Size $_{i, t}$} & $6.833^{* * *}$ & $6.825^{* * *}$ & $0.243^{* * *}$ & $0.240^{* * *}$ \\
\hline & (16.05) & $(19.04)$ & $(14.20)$ & $(16.32)$ \\
\hline \multirow[t]{2}{*}{$R O A_{i, t}$} & $66.604^{* * *}$ & $84.315^{* * *}$ & $1.684^{* * *}$ & $1.786^{* * *}$ \\
\hline & $(8.67)$ & $(14.04)$ & $(5.45)$ & $(7.25)$ \\
\hline \multirow[t]{2}{*}{ Leverage $_{i, t}$} & $-7.241^{* * *}$ & $-5.911^{* * *}$ & $-0.242^{* *}$ & $-0.165^{* *}$ \\
\hline & $(-3.03)$ & $(-3.05)$ & $(-2.52)$ & $(-2.08)$ \\
\hline \multirow[t]{2}{*}{ Intercept } & $-121.646^{* * *}$ & $-134.466^{* * *}$ & $-2.983^{* * *}$ & $-3.412^{* * *}$ \\
\hline & $(-12.72)$ & $(-16.34)$ & $(-7.75)$ & $(-10.11)$ \\
\hline Year & Yes & Yes & Yes & Yes \\
\hline Industry & Yes & Yes & Yes & Yes \\
\hline Observations & 2248 & 2248 & 2248 & 2248 \\
\hline Adjusted $R$-squared & 0.32 & 0.38 & 0.25 & 0.28 \\
\hline
\end{tabular}

Notes. (1) ${ }^{* * * * *},{ }^{*}{ }^{*}$ indicates significance levels at $0.01,0.05$, and 0.10 , respectively, using two tailed tests. (2) We report in parentheses $t$-statistics based on standard errors that are clustered within firm, and are robust to heteroscedasticity. (3) All the continuous variables are winsorized at 1 and 99\%. (4) See Appendix A for variable definitions

\section{Heckman two-stage sample selection method}

A firm's decision to engage in CSR may not be random. We adopt the Heckman twostage sample selection method as a robustness check to control the potential selfselection bias (Heckman 1979). In the first step, we estimate a probit model with a binary returnee managers dummy (Returnee (0/1), which equals 1 if a firm has at least one returnee manager, 0 otherwise) as the dependent variable. Heckman's estimator needs an exogenous variable that is correlated with a firm's probability of employing returnee managers, but not correlated with CSR. We use Mean_Returnee (the mean percentage of hiring returnee managers by other firms in the same industry and year). The specification of the Probit model is the same as model (2) except for adding 
Mean_returnee. The untabulated first-stage regression shows that Mean_returnee is positively associated with Returnee (0/1). Inverse Mills Ratio (IMR) is generated in the first stage and included in the second-step model to control for potential selfselection bias.

Table 6 reports the second-stage regression results of the Heckman model. We can see that when IMR is included, Returnee (0/1) and Returnee number are still positively correlated with CSR, demonstrating that returnee managers enhance firms' willingness to engage in CSR.

Table 6 Regression Results of Heckman Two-stage Sample Selection Method

\begin{tabular}{|c|c|c|c|c|}
\hline & \multicolumn{2}{|c|}{$Y=$ CSR_Score $i, t$} & \multicolumn{2}{|c|}{$Y=C S R \_$Rate ${ }_{i, t}$} \\
\hline & (1) & $(2)$ & (3) & $(4)$ \\
\hline \multirow[t]{2}{*}{ Returnee $(0 / 1)_{i, t}$} & $1.709^{* *}$ & & $0.078^{* *}$ & \\
\hline & $(2.10)$ & & $(2.39)$ & \\
\hline \multirow[t]{2}{*}{ Returnee number i,t } & & $1.318^{* * *}$ & & $0.058^{* * *}$ \\
\hline & & $(2.71)$ & & $(2.84)$ \\
\hline \multirow[t]{2}{*}{ State control $(0 / 1)_{i, t}$} & -1.900 & -1.888 & -0.070 & -0.070 \\
\hline & $(-1.43)$ & $(-1.42)$ & $(-1.46)$ & $(-1.44)$ \\
\hline \multirow[t]{2}{*}{ Board Independence $_{i, t}$} & $10.102^{*}$ & $10.288^{*}$ & 0.339 & 0.348 \\
\hline & $(1.74)$ & $(1.77)$ & $(1.48)$ & $(1.52)$ \\
\hline \multirow[t]{2}{*}{ Power balance $i, t$} & -0.046 & -0.046 & $-0.002^{*}$ & $-0.002^{*}$ \\
\hline & $(-1.21)$ & $(-1.21)$ & $(-1.75)$ & $(-1.75)$ \\
\hline \multirow[t]{2}{*}{ Duality $(0 / 1)_{i, t}$} & -0.609 & -0.606 & -0.021 & -0.021 \\
\hline & $(-1.07)$ & $(-1.06)$ & $(-0.96)$ & $(-0.95)$ \\
\hline \multirow[t]{2}{*}{ Managerial ownership $i, t$} & $2.983^{*}$ & $3.062^{*}$ & 0.040 & 0.043 \\
\hline & $(1.70)$ & $(1.74)$ & $(0.59)$ & $(0.64)$ \\
\hline \multirow[t]{2}{*}{ Institutional ownership $i, t$} & $12.859^{* * *}$ & $12.902^{* * *}$ & $0.466^{* * *}$ & $0.468^{* * *}$ \\
\hline & $(8.95)$ & $(9.00)$ & $(8.26)$ & $(8.32)$ \\
\hline \multirow[t]{2}{*}{ Firm age $i, t$} & 0.083 & 0.080 & 0.003 & 0.003 \\
\hline & $(1.42)$ & $(1.36)$ & $(1.44)$ & $(1.38)$ \\
\hline \multirow[t]{2}{*}{ Size $_{i, t}$} & $5.998^{* * *}$ & $5.952^{* * *}$ & $0.189^{* * *}$ & $0.187^{* * *}$ \\
\hline & $(21.70)$ & $(21.41)$ & $(17.62)$ & $(17.36)$ \\
\hline \multirow[t]{2}{*}{$R O A_{i, t}$} & $75.635^{* * *}$ & $75.679^{* * *}$ & $1.539^{* * *}$ & $1.540^{* * *}$ \\
\hline & $(19.15)$ & $(19.16)$ & $(10.87)$ & $(10.89)$ \\
\hline \multirow[t]{2}{*}{ Leverage $_{i, t}$} & $-4.934^{* * *}$ & $-4.905^{* * *}$ & $-0.087^{*}$ & $-0.086^{*}$ \\
\hline & $(-3.92)$ & $(-3.90)$ & $(-1.91)$ & $(-1.88)$ \\
\hline \multirow[t]{2}{*}{ Inverse Mills Ratio } & $9.872^{* * *}$ & $9.742^{* * *}$ & $0.451^{* * *}$ & $0.447^{* * *}$ \\
\hline & $(4.51)$ & $(4.37)$ & $(4.95)$ & $(4.81)$ \\
\hline \multirow[t]{2}{*}{ Intercept } & $-117.146^{* * *}$ & $-116.201^{* * *}$ & $-2.312^{* * *}$ & $-2.270^{* * *}$ \\
\hline & $(-18.03)$ & $(-17.80)$ & $(-9.08)$ & $(-8.89)$ \\
\hline Year & Yes & Yes & Yes & Yes \\
\hline Industry & Yes & Yes & Yes & Yes \\
\hline Observations & 9519 & 9519 & 9519 & 9519 \\
\hline Adjusted $R$-squared & 0.34 & 0.34 & 0.23 & 0.23 \\
\hline
\end{tabular}

Notes. (1) ${ }^{* * * * *},{ }^{*}{ }^{*}$ indicates significance levels at $0.01,0.05$, and 0.10 , respectively, using two tailed tests. (2) We report in parentheses $t$-statistics based on standard errors that are clustered within firm, and are robust to heteroscedasticity. (3) All the continuous variables are winsorized at 1 and 99\%. (4) See Appendix A for variable definitions 


\section{Alternative measures of CSR}

In order to ensure that our results are not driven by the way we measure CSR, we use alternative ways to construct the CSR measure. Following Quan et al. (2015), we use the dataset of CSR Reports \& Ratings Searching Centre for listed companies released by RKS. We construct two variables RKS_Score and RKS_Rate, as proxies for CSR. The higher RKS_Score and RKS_Rate represent better CSR performance. Table 7 reports the regression results using alternative measure of CSR performance. All of these measures yield similar results.

\section{Alternative definition of returnee managers}

The measure of returnee managers is also important in our research. In order to ensure the authenticity and validity of managerial foreign experience, we exclude managers with only Hong Kong, Macau, and Taiwan experience since these places have very similar geographical and cultural values as Chinese mainland. The untabulated results suggest that managerial foreign experience still has a significantly effect on CSR. ${ }^{7}$

To summarize, we conclude that returnee managers have a positive effect on CSR after a series of robustness checks.

\section{Further analyses}

\section{Managerial foreign study experience and Work experience}

Returnee managers' foreign experience can be divided into foreign study experience and foreign work experience. Compared with managers with only foreign work experience, managers with foreign study experience have obtained more in depth and extended CSR education in foreign countries, and have a better sense of CSR. They are more capable of implementing advanced CSR concepts and corporate values at their firms. Thus, we predict that managers with foreign study experience have a greater influence on CSR than managers with foreign work experience. We test the foreign study experience and work experience by examining the following model:

$$
\begin{aligned}
\operatorname{CSR}_{i, t}= & \beta_{0}+\beta_{1}{\text { Returnee work }(0 / 1)_{i, t}}+\beta_{2} \text { Returnee study }(0 / 1)_{i, t} \\
& +\beta_{3} \text { Controls }_{i, t} \\
& + \text { Industry }+ \text { Year }+\varepsilon
\end{aligned}
$$

where $\beta_{O}$ is the intercept, $\beta_{i}$ represents regression coefficients, $\varepsilon$ is an error term. Returnee work $(0 / 1)$ is a dummy variable which equals 1 if firm $i$ has at least one returnee manager with foreign work experience, otherwise it equals 0 . Returnee study is a dummy variable which equals 1 if firm $i$ has at least one manager with foreign work experience, otherwise it equals 0 . If the effect of returnee managers on CSR is more pronounced when they have a foreign study background compared to managerial foreign work experience, the coefficients of $\beta_{1}$ and $\beta_{2}$ should both be positive and $\beta_{2}$ is larger than $\beta_{1}$.

Table 8 reports the regression results. Returnee work (0/1) in columns (1) and (3) is positive but insignificant, while those of Returnee study (0/1) in columns (2) and (4) are positively significant at the 5\% (1\%) level, demonstrating that the effect of managerial foreign study experience on CSR is more pronounced than managerial foreign work experience. 
Table 7 CSR Measured by RKS Index

\begin{tabular}{|c|c|c|c|c|}
\hline & \multicolumn{2}{|l|}{ RKS_Score $i, t$} & \multicolumn{2}{|l|}{ RKS_Level i,t } \\
\hline & (1) & (2) & (3) & (4) \\
\hline \multirow[t]{2}{*}{ Returnee $(0 / 1)_{i, t}$} & $3.182^{* * *}$ & & $0.794^{* * *}$ & \\
\hline & $(2.63)$ & & $(2.79)$ & \\
\hline \multirow[t]{2}{*}{ Returnee number $i, t$} & & $1.913^{* *}$ & & $0.475^{* *}$ \\
\hline & & $(2.41)$ & & $(2.52)$ \\
\hline \multirow[t]{2}{*}{ State control $(0 / 1) i, t$} & -1.724 & -1.711 & -0.271 & -0.268 \\
\hline & $(-0.95)$ & $(-0.92)$ & $(-0.59)$ & $(-0.57)$ \\
\hline \multirow[t]{2}{*}{ Board Independence $_{i, t}$} & -4.232 & -3.830 & -1.384 & -1.285 \\
\hline & $(-0.47)$ & $(-0.43)$ & $(-0.66)$ & $(-0.61)$ \\
\hline \multirow[t]{2}{*}{ Power balance $i, t$} & -0.040 & -0.038 & -0.006 & -0.005 \\
\hline & $(-0.67)$ & $(-0.65)$ & $(-0.41)$ & $(-0.38)$ \\
\hline \multirow[t]{2}{*}{ Duality $(0 / 1) i, t$} & -0.762 & -0.757 & -0.137 & -0.136 \\
\hline & $(-0.93)$ & $(-0.94)$ & $(-0.70)$ & $(-0.70)$ \\
\hline \multirow[t]{2}{*}{ Managerial ownership $i, t$} & 1.100 & 1.444 & 0.685 & 0.772 \\
\hline & $(0.35)$ & $(0.45)$ & $(0.90)$ & $(1.00)$ \\
\hline \multirow[t]{2}{*}{ Institutional ownership i,t } & 1.463 & 1.721 & 0.447 & 0.510 \\
\hline & $(0.69)$ & $(0.81)$ & $(0.89)$ & $(1.01)$ \\
\hline \multirow[t]{2}{*}{ Firm age $i, t$} & $-0.270^{* *}$ & $-0.269^{* *}$ & $-0.056^{* *}$ & $-0.056^{* *}$ \\
\hline & $(-2.39)$ & $(-2.37)$ & $(-2.06)$ & $(-2.04)$ \\
\hline \multirow[t]{2}{*}{ Size $_{i, t}$} & $3.928^{* * *}$ & $3.837^{* * *}$ & $0.956^{* * *}$ & $0.934^{* * *}$ \\
\hline & (7.99) & $(7.99)$ & $(8.17)$ & $(8.21)$ \\
\hline \multirow[t]{2}{*}{$R O A_{i, t}$} & 7.008 & 7.496 & 1.742 & 1.868 \\
\hline & $(1.16)$ & $(1.22)$ & $(1.18)$ & $(1.25)$ \\
\hline \multirow[t]{2}{*}{ Leverage $_{i, t}$} & -0.937 & -1.042 & -0.233 & -0.259 \\
\hline & $(-0.39)$ & $(-0.43)$ & $(-0.40)$ & $(-0.45)$ \\
\hline \multirow[t]{2}{*}{ Intercept } & $-43.271^{* * *}$ & $-41.373^{* * *}$ & $-12.944^{* * *}$ & $-12.487^{* * *}$ \\
\hline & $(-3.90)$ & $(-3.81)$ & $(-4.89)$ & $(-4.84)$ \\
\hline Year & Yes & Yes & Yes & Yes \\
\hline Industry & Yes & Yes & Yes & Yes \\
\hline Observations & 2414 & 2414 & 2391 & 2391 \\
\hline Adjusted R-squared & 0.21 & 0.22 & 0.21 & 0.22 \\
\hline
\end{tabular}

Notes. (1) ${ }^{* * *},{ }^{* *},{ }^{*}$ indicates significance levels at $0.01,0.05$, and 0.10 , respectively, using two tailed tests. (2) We report in parentheses $t$-statistics based on standard errors that are clustered within firm, and are robust to heteroscedasticity. (3) All the continuous variables are winsorized at 1 and 99\%. (4) See Appendix A for variable definitions

\section{Managers with experience from developed economies}

Different country origins may affect the relationship between managerial foreign experience and CSR performance. Managers who have obtained experience in developed economies may bring the advanced value of CSR and promote CSR performance in emerging economies such as China. However, this logic may not hold when managers obtained their foreign experience in an emerging economy. From the descriptive statistics in Section 4.2, we can see that nearly $99.2 \%$ of returnee managers obtained their experience in developed economies. This is consistent with the phenomena in China whereby young people are eager to go to advanced economies to pursue better education and working opportunities. To further 
Table 8 Managerial Foreign Work Experience and Foreign Study Experience

\begin{tabular}{|c|c|c|c|c|}
\hline & \multicolumn{2}{|c|}{$Y=C S R \_$Score $_{i, t}$} & \multicolumn{2}{|c|}{$Y=C S R \_$Rate $_{i, t}$} \\
\hline & (1) & (2) & (3) & (4) \\
\hline \multirow[t]{2}{*}{ Returnee work $(0 / 1) i, t$} & 1.400 & & 0.068 & \\
\hline & $(1.09)$ & & $(1.30)$ & \\
\hline \multirow[t]{2}{*}{ Returnee study $(0 / 1)$ i,t } & & $2.199^{* *}$ & & $0.097^{* * *}$ \\
\hline & & $(2.47)$ & & $(2.72)$ \\
\hline \multirow[t]{2}{*}{ State control $(0 / 1)_{i, t}$} & $-2.372^{*}$ & $-2.332^{*}$ & $-0.092^{*}$ & $-0.090^{*}$ \\
\hline & $(-1.79)$ & $(-1.76)$ & $(-1.90)$ & $(-1.86)$ \\
\hline \multirow[t]{2}{*}{ Board Independence $_{i, t}$} & $11.141^{*}$ & $10.711^{*}$ & $0.387^{*}$ & 0.368 \\
\hline & $(1.92)$ & $(1.85)$ & $(1.70)$ & $(1.61)$ \\
\hline \multirow[t]{2}{*}{ Power balance $i, t$} & $-0.071^{*}$ & $-0.068^{*}$ & $-0.004^{* *}$ & $-0.003^{* *}$ \\
\hline & $(-1.87)$ & $(-1.80)$ & $(-2.54)$ & $(-2.47)$ \\
\hline \multirow[t]{2}{*}{ Duality $(0 / 1) i, t$} & -0.712 & -0.694 & -0.026 & -0.025 \\
\hline & $(-1.25)$ & $(-1.21)$ & $(-1.17)$ & $(-1.13)$ \\
\hline \multirow[t]{2}{*}{ Managerial ownership $i, t$} & 1.272 & 1.372 & -0.038 & -0.034 \\
\hline & $(0.73)$ & $(0.79)$ & $(-0.57)$ & $(-0.51)$ \\
\hline \multirow[t]{2}{*}{ Institutional ownership i,t } & $12.556^{* * *}$ & $12.536^{* * *}$ & $0.452^{* * *}$ & $0.451^{* * *}$ \\
\hline & $(8.71)$ & $(8.69)$ & $(8.00)$ & $(7.98)$ \\
\hline \multirow[t]{2}{*}{ Firm age ${ }_{i, t}$} & 0.058 & 0.060 & 0.002 & 0.002 \\
\hline & $(1.00)$ & $(1.03)$ & $(0.95)$ & $(0.98)$ \\
\hline \multirow[t]{2}{*}{ Size $_{i, t}$} & $6.418^{* * *}$ & $6.365^{* * *}$ & $0.208^{* * *}$ & $0.206^{* * *}$ \\
\hline & $(23.46)$ & $(23.18)$ & $(19.66)$ & $(19.41)$ \\
\hline \multirow[t]{2}{*}{$R O A_{i, t}$} & $76.623^{* * *}$ & $76.585^{* * *}$ & $1.584^{* * *}$ & $1.582^{* * *}$ \\
\hline & $(19.37)$ & $(19.38)$ & $(11.19)$ & (11.19) \\
\hline \multirow[t]{2}{*}{ Leverage $_{i, t}$} & $-5.104^{* * *}$ & $-5.100^{* * *}$ & $-0.095^{* *}$ & $-0.095^{* *}$ \\
\hline & $(-4.04)$ & $(-4.05)$ & $(-2.06)$ & $(-2.07)$ \\
\hline \multirow[t]{2}{*}{ Intercept } & $-124.760^{* * *}$ & $-123.675^{* * *}$ & $-2.659^{* * * *}$ & $-2.613^{* * *}$ \\
\hline & $(-19.23)$ & $(-19.02)$ & $(-10.49)$ & $(-10.30)$ \\
\hline Year & Yes & Yes & Yes & Yes \\
\hline Industry & Yes & Yes & Yes & Yes \\
\hline Observations & 9519 & 9519 & 9519 & 9519 \\
\hline Adjusted R-squared & 0.33 & 0.34 & 0.23 & 0.23 \\
\hline
\end{tabular}

Notes. (1) ${ }^{* * * * *},{ }^{*}{ }^{*}$ indicates significance levels at $0.01,0.05$, and 0.10 , respectively, using two tailed tests. (2) We report in parentheses $t$-statistics based on standard errors that are clustered within firm, and are robust to heteroscedasticity. (3) All the continuous variables are winsorized at 1 and 99\%. (4) See Appendix A for variable definitions

illustrate the country effect on CSR performance, we employ model (4) to test whether returnee managers from advance economies have a stronger effect on CSR performance.

$$
\operatorname{CSR}_{i, t}=\beta_{0}+\beta_{1} \text { Returnee developed }_{i, t}+\beta_{2} \text { Controls }_{i, t}+\text { Industry }+ \text { Year }+\varepsilon,
$$

where $\beta_{O}$ is the intercept, $\beta_{i}$ represents regression coefficients, $\varepsilon$ is an error term. The variables of interest are: (1) Returnee developed (0/1), a dummy variable equals 1 if firm $i$ has at least one manager who obtained his overseas experience from at least one developed economy in year $t$ and 0 otherwise; and, (2) Returnee number, number of managers who obtained experience from advanced economies. If 
returnee managers from developed economies have a stronger effect on CSR performance, the coefficients of $\beta_{1}$ should be positive, and the magnitudes should be larger than those in model (1).

Table 9 presents the regression results. Returnee developed (0/1) and Returnee number are both positively significant and the magnitudes of coefficients and significances are larger than those in Table 3. The result further implies that only when managers had experience in developed economies can they bring advanced CSR values and promote CSR performance in China.

\section{Information asymmetry, returnee managers and CSR}

Asymmetric information theory suggests that one party has more or better information than the other during economic transactions. People in a position of information superiority can benefit from the market by communicating reliable information to the party with an information disadvantage. CSR is a wise choice that is both self-serving and altruistic (Walsh and Beatty 2007). CSR itself is not a resource, but can convey positive signals to stakeholders, establish a good corporate image, and gain trust from stakeholders (Chahal and Sharma 2006; Peloza 2006; Fernandez-Feijoo et al. 2014). Previous studies demonstrate that developing a corporate reputation for being socially responsible is part of a strategic plan in managing stakeholder relationships (Roberts 2004). Corporate social disclosure can reduce information asymmetries between firms and their stakeholders, improve the accuracy of analysts' prediction (Dhaliwal et al., 2012), reduce the cost of capital (Dhaliwal et al., 2011; Ghoul et al. 2011; Goss and Roberts 2011; Oikonomou et al. 2014), and leave the firm better placed for future investment advantages. As well, managers can use CSR to achieve their social, political and career goals (Friedman 1970).

Returnee managers are regarded as high-level talents since they have a global vision and good communication skills, and they are still scarce in the Chinese human resources market at this stage. These talents are much in demand of enterprises hoping to achieve and sustain competitive advantages in the international market. These individuals have devoted considerable funds, time and effort to support their study and work experience. Their society, as well as the individuals themselves, have high expectations and stringent requirements. Therefore, due to the social reputation mechanism and the consideration of personal career development, returnee managers are more willing to cultivate trust and support from stakeholders through better CSR performance. Thus, from the perspective of information asymmetry, we predict that the impact of managerial foreign experience is more pronounced when companies face greater information asymmetry.

Following Quan et al. (2015) and Wang et al. (2015), we use earnings management to measure the degree of information asymmetry of listed companies. We adopt the modified Jones model (Dechow et al. 1995) to calculate earnings management. First using the following model in the estimation period to estimate the firm-specific parameters $\alpha_{1}, \alpha_{2}$, and $\alpha_{3}$ :

$$
T A_{t}=\alpha_{1} \frac{1}{A_{t-1}}+\alpha_{2} \frac{\left(\Delta R E V_{t}-\Delta R E C_{t}\right)}{\overline{A_{t-1}}}+\alpha_{3} \frac{P P E_{t}}{A_{t-1}}+\text { Year }+ \text { Industry }+\varepsilon
$$


Table 9 Managers Obtained Experience from Developed Countries

\begin{tabular}{|c|c|c|c|c|}
\hline & \multicolumn{2}{|c|}{$Y=$ CSR_Score ${ }_{i, t}$} & \multicolumn{2}{|c|}{$Y=$ CSR_Rate ${ }_{i, t}$} \\
\hline & $(1)$ & (2) & (3) & (4) \\
\hline \multirow[t]{2}{*}{ Returnee developed $(0 / 1) i, t$} & $2.066^{* *}$ & & $0.097^{* * *}$ & \\
\hline & $(2.50)$ & & $(2.95)$ & \\
\hline \multirow[t]{2}{*}{ Returnee number developed $i, t$} & & $1.584^{* * *}$ & & $0.072^{* * *}$ \\
\hline & & $(3.20)$ & & (3.49) \\
\hline \multirow[t]{2}{*}{ State control $(0 / 1)$ i,t } & $-2.317^{*}$ & $-2.294^{*}$ & $-0.089^{*}$ & $-0.088^{*}$ \\
\hline & $(-1.75)$ & $(-1.73)$ & $(-1.85)$ & $(-1.83)$ \\
\hline \multirow[t]{2}{*}{ Board Independence $_{i, t}$} & $10.840^{*}$ & $10.994^{*}$ & 0.373 & $0.380^{*}$ \\
\hline & $(1.87)$ & $(1.90)$ & $(1.63)$ & $(1.67)$ \\
\hline \multirow[t]{2}{*}{ Power balance $i, t$} & $-0.067^{*}$ & $-0.067^{*}$ & $-0.003^{* *}$ & $-0.003^{* *}$ \\
\hline & $(-1.78)$ & $(-1.77)$ & $(-2.44)$ & $(-2.43)$ \\
\hline \multirow[t]{2}{*}{ Duality $(0 / 1)_{i, t}$} & -0.702 & -0.700 & -0.025 & -0.025 \\
\hline & $(-1.23)$ & $(-1.22)$ & $(-1.15)$ & $(-1.14)$ \\
\hline \multirow[t]{2}{*}{ Managerial ownership i,t } & 1.390 & 1.523 & -0.033 & -0.027 \\
\hline & $(0.80)$ & $(0.88)$ & $(-0.49)$ & $(-0.40)$ \\
\hline \multirow[t]{2}{*}{ Institutional ownership i,t } & $12.569^{* * *}$ & $12.622^{* * *}$ & $0.453^{* * *}$ & $0.455^{* * *}$ \\
\hline & $(8.72)$ & $(8.78)$ & $(8.01)$ & $(8.08)$ \\
\hline \multirow[t]{2}{*}{ Firm age $_{i, t}$} & 0.059 & 0.057 & 0.002 & 0.002 \\
\hline & $(1.01)$ & $(0.97)$ & $(0.97)$ & $(0.91)$ \\
\hline \multirow[t]{2}{*}{ Size $_{i, t}$} & $6.364^{* * *}$ & $6.308^{* * *}$ & $0.206^{* * *}$ & $0.203^{* * *}$ \\
\hline & (23.18) & $(22.86)$ & $(19.40)$ & (19.09) \\
\hline \multirow[t]{2}{*}{$R O A_{i, t}$} & $76.618^{* * *}$ & $76.658^{* * *}$ & $1.584^{* * *}$ & $1.585^{* * *}$ \\
\hline & $(19.43)$ & (19.43) & $(11.23)$ & $(11.25)$ \\
\hline \multirow[t]{2}{*}{ Leverage $_{i, t}$} & $-5.075^{* * *}$ & $-5.047^{* * *}$ & $-0.094^{* *}$ & $-0.092^{* *}$ \\
\hline & $(-4.03)$ & $(-4.01)$ & $(-2.04)$ & $(-2.02)$ \\
\hline \multirow[t]{2}{*}{ Intercept } & $-123.730^{* * *}$ & $-122.563^{* * *}$ & $-2.611^{* * *}$ & $-2.560^{* * *}$ \\
\hline & $(-19.02)$ & $(-18.78)$ & $(-10.30)$ & $(-10.07)$ \\
\hline Year & Yes & Yes & Yes & Yes \\
\hline Industry & Yes & Yes & Yes & Yes \\
\hline Observations & 9519 & 9519 & 9519 & 9519 \\
\hline Adjusted $R$-squared & 0.34 & 0.34 & 0.23 & 0.23 \\
\hline
\end{tabular}

Notes. (1) ${ }^{* * *},{ }^{* *},{ }^{*}$ indicates significance levels at $0.01,0.05$, and 0.10 , respectively, using two tailed tests. (2) We report in parentheses $t$-statistics based on standard errors that are clustered within firm, and are robust to heteroscedasticity. (3) All the continuous variables are winsorized at 1 and 99\%. (4) See Appendix A for variable definitions

where $T A_{t}=$ total accruals scaled by total assets in year $t-1$, calculated by operating income in year $t$ minus net operating cash flow in year $t$.

$\triangle R E V_{t}=$ the change of revenue from year $t-1$ to year $t$.

$\triangle R E C_{t}=$ the change of accounts receivable from year $t-1$ to year $t$.

$P P E_{t}=$ property, plant and equipment in year $t$.

$A_{t}=$ total assets in year $t$.

$\alpha_{1}, \alpha_{2}, \alpha_{3}=$ firm-specific parameters.

Then we use the firm-specific parameters to estimate the nondiscretionary accruals in the event year: 


$$
N D A_{t}=\alpha_{1} \frac{1}{A_{t-1}}+\alpha_{2} \frac{\left(\Delta R E V_{t}-\Delta R E C_{t}\right)}{\overline{A_{t-1}}}+\alpha_{3} \frac{P P E_{t}}{A_{t-1}},
$$

where $N D A_{t}$ is the nondiscretionary accruals scaled by total assets.

Discretionary accruals $(D A)$ is the difference between total accruals and nondiscretionary accruals. The larger $D A$ represents more earnings management, and thus larger information asymmetry.

To test the association between managerial foreign experience and CSR in different degrees of information asymmetries, we divided our sample into two groups. One group represents higher information asymmetry (Column (1)-(2) in Table 10) and the other group lower information asymmetry (Column (3)-(4) in Table 10). We run the regression model (1) again and the results are presented in Table 10. It shows that returnee managers have a more significant impact on CSR when firms face greater information asymmetry, demonstrating that returnee managers are eager to use CSR to transmit positive signals to stakeholders Table 10 .

There might be an alternative explanation as to why returnee managers would like to invest in CSR. If CSR is merely a waste of shareholders' money used for building a manager's own reputation, returnee managers would have a greater propensity to increase CSR performance especially when information asymmetry is higher. To examine this explanation, we further test whether CSR could reduce information asymmetry by testing whether CSR improves firm value.

$$
\begin{aligned}
\text { Tobin's } Q_{i, t}= & \beta_{0}+\beta_{1} \operatorname{CSR}_{i, t}+\beta_{2} \text { Returnee }(0 / 1)_{i, t}+\beta_{3} \text { Controls }_{i, t}+\text { Industry } \\
& + \text { Year }+\varepsilon
\end{aligned}
$$

We employ model (7) to test the impact of CSR on firm value. Follow Harjoto and Jo (2011), we use Tobin's Q to proxy for firm value. Tobin's Q1 equals to the sum of book value and total liabilities divided by total assets, and Tobin's Q2 equals to the sum of book value, short-term debt, long-term debt, and bonds payable, divided by total assets. The main dependent variable is CSR. If $\beta$ is positively significant, that suggests that CSR investment has a positive impact on firm value.

Table 11 reports the regression results. We find that the coefficients on CSR_Score and CSR_Level are all positive and significant at 1\% level, indicating that CSR can help managers to reduce information asymmetry and improve firm value.

\section{Conclusion}

Corporate social responsibility has attracted worldwide attention since the 1990s. The determinants of managerial background on CSR performance have not been fully explored. Our study investigates the impact of returnee managers on CSR using hand collected managerial foreign background information data for the period 2010-2014. Our empirical evidence shows that returnee managers have a positive effect on CSR, and that this effect only holds when managers obtained experience in advanced economies. Our results are robust after using the propensity score matching procedure, Heckman two-stage sample selection method, alternative measure of CSR, and alternative definition of returnee managers. 
Table 10 Information Asymmetry, Returnee Managers and CSR

\begin{tabular}{|c|c|c|c|c|}
\hline \multirow[t]{2}{*}{$\mathrm{Y}=$ CSR_Score $\mathrm{i}, \mathrm{t}$} & \multicolumn{2}{|c|}{$D A>$ Median } & \multicolumn{2}{|c|}{$D A<$ Median } \\
\hline & $(1)$ & (2) & (3) & (4) \\
\hline \multirow[t]{2}{*}{ Returnee $(0 / 1)_{i, t}$} & $2.350^{* *}$ & & $1.660^{*}$ & \\
\hline & $(2.16)$ & & $(1.70)$ & \\
\hline \multirow[t]{2}{*}{ Returnee number ${ }_{i, t}$} & & $1.937^{* * *}$ & & 0.923 \\
\hline & & (3.38) & & $(1.48)$ \\
\hline \multirow[t]{2}{*}{ State control $(0 / 1)$ i,t } & -1.419 & -1.400 & $-3.406^{* *}$ & $-3.400^{* *}$ \\
\hline & $(-0.71)$ & $(-0.70)$ & $(-2.41)$ & $(-2.41)$ \\
\hline \multirow[t]{2}{*}{ Board independence $_{i, t}$} & 10.220 & 10.888 & 10.810 & 10.809 \\
\hline & $(1.29)$ & $(1.38)$ & $(1.57)$ & $(1.58)$ \\
\hline \multirow[t]{2}{*}{ Power balance $i, t$} & $-0.082^{*}$ & $-0.083^{*}$ & -0.057 & -0.057 \\
\hline & $(-1.70)$ & $(-1.73)$ & $(-1.20)$ & $(-1.20)$ \\
\hline \multirow[t]{2}{*}{ Duality $(0 / 1)_{i, t}$} & $-1.475^{*}$ & $-1.477^{*}$ & -0.003 & -0.001 \\
\hline & $(-1.94)$ & $(-1.95)$ & $(-0.00)$ & $(-0.00)$ \\
\hline \multirow[t]{2}{*}{ Managerial ownership $i, t$} & 0.045 & 0.293 & 2.370 & 2.330 \\
\hline & $(0.02)$ & $(0.13)$ & $(1.23)$ & $(1.21)$ \\
\hline \multirow[t]{2}{*}{ Institutional ownership i,t } & $10.197^{* * *}$ & $10.300^{* * *}$ & $15.135^{* * *}$ & $15.170^{* * *}$ \\
\hline & $(5.54)$ & $(5.62)$ & $(8.19)$ & $(8.22)$ \\
\hline \multirow[t]{2}{*}{ Firm age $_{i, t}$} & 0.070 & 0.068 & 0.041 & 0.038 \\
\hline & $(0.89)$ & $(0.87)$ & $(0.63)$ & $(0.57)$ \\
\hline \multirow[t]{2}{*}{ Size $_{i, t}$} & $7.106^{* * *}$ & $7.018^{* * *}$ & $5.803^{* * *}$ & $5.783^{* * *}$ \\
\hline & $(18.77)$ & $(18.44)$ & $(18.25)$ & $(18.10)$ \\
\hline \multirow[t]{2}{*}{$R O A_{i, t}$} & $81.707^{* * *}$ & $81.651^{* * *}$ & $73.754^{* * *}$ & $73.796^{* * *}$ \\
\hline & $(12.97)$ & $(12.91)$ & $(16.56)$ & $(16.57)$ \\
\hline \multirow[t]{2}{*}{ Leverage $_{i, t}$} & $-8.577^{* * *}$ & $-8.494^{* * *}$ & $-2.663^{*}$ & $-2.670^{*}$ \\
\hline & $(-4.70)$ & $(-4.65)$ & $(-1.81)$ & $(-1.81)$ \\
\hline \multirow[t]{2}{*}{ Intercept } & $-138.456^{* * *}$ & $-136.844^{* * *}$ & $-112.011^{* * *}$ & $-111.470^{* * *}$ \\
\hline & $(-15.43)$ & $(-15.18)$ & $(-14.63)$ & $(-14.55)$ \\
\hline Year & Yes & Yes & Yes & Yes \\
\hline Industry & Yes & Yes & Yes & Yes \\
\hline Observations & 4631 & 4631 & 4888 & 4888 \\
\hline Adjusted $R$-squared & 0.32 & 0.32 & 0.36 & 0.36 \\
\hline
\end{tabular}

Notes. (1) ${ }^{* * *},{ }^{* *},{ }^{*}$ indicates significance levels at $0.01,0.05$, and 0.10 , respectively, using two tailed tests. (2) We report in parentheses $t$-statistics based on standard errors that are clustered within firm, and are robust to heteroscedasticity. (3) All the continuous variables are winsorized at 1 and 99\%. (4) See Appendix A for variable definitions. (5) We can get similar results when we use CSR_Rate to proxy for CSR, the results are available upon requests

Further tests show that compared with managerial foreign work experience, managerial foreign study experience has a greater impact on CSR. In addition, when firms face greater information asymmetry, returnee managers are more willing to use CSR performance to send signals to stakeholders. CSR can help managers reduce information asymmetry and improve firm value.

Our paper makes several contributions. A recent strand of managerial characteristic literature focuses on the role of managerial foreign experience. Giannetti et al. (2015) demonstrate that returnee managers increase firm performance. Our findings on the positive relations between returnee managers and CSR performance fit into 
Table 11 CSR and Firm Value

\begin{tabular}{|c|c|c|c|c|}
\hline & \multicolumn{2}{|c|}{$Y=$ Tobin's $Q 1$ i,t } & \multicolumn{2}{|c|}{$Y=$ Tobin's $Q 2$ i,t } \\
\hline & $(1)$ & $(2)$ & (3) & (4) \\
\hline \multirow[t]{2}{*}{ CSR_Score $i, t$} & $0.007^{* * *}$ & & $0.006^{* * *}$ & \\
\hline & $(6.87)$ & & $(6.55)$ & \\
\hline \multirow[t]{2}{*}{ CSR_Level i,t } & & $0.179^{* * *}$ & & $0.170^{* * *}$ \\
\hline & & $(7.36)$ & & $(7.07)$ \\
\hline \multirow[t]{2}{*}{ Returnee $(0 / 1)$ i,t } & $0.237^{* * *}$ & $0.233^{* * *}$ & $0.233^{* * *}$ & $0.230^{* * *}$ \\
\hline & $(4.44)$ & $(4.38)$ & $(4.37)$ & $(4.31)$ \\
\hline \multirow[t]{2}{*}{ State control $(0 / 1) i, t$} & 0.016 & 0.016 & 0.026 & 0.026 \\
\hline & $(0.17)$ & $(0.18)$ & $(0.27)$ & $(0.28)$ \\
\hline \multirow[t]{2}{*}{ Board Independence $_{i, t}$} & $1.320^{* * *}$ & $1.323^{* * *}$ & $1.355^{* * *}$ & $1.357^{* * *}$ \\
\hline & $(3.41)$ & $(3.43)$ & (3.54) & (3.56) \\
\hline \multirow[t]{2}{*}{ Power balance $i, t$} & $-0.005^{* *}$ & $-0.005^{* *}$ & $-0.005^{* *}$ & $-0.005^{* *}$ \\
\hline & $(-2.53)$ & $(-2.45)$ & $(-2.54)$ & $(-2.46)$ \\
\hline \multirow[t]{2}{*}{ Duality $(0 / 1)_{i, t}$} & -0.004 & -0.004 & -0.003 & -0.004 \\
\hline & $(-0.09)$ & $(-0.10)$ & $(-0.08)$ & $(-0.09)$ \\
\hline \multirow[t]{2}{*}{ Managerial ownership i,t } & $-0.279^{* *}$ & $-0.265^{* *}$ & $-0.253^{*}$ & $-0.240^{*}$ \\
\hline & $(-2.09)$ & $(-1.99)$ & $(-1.91)$ & $(-1.82)$ \\
\hline \multirow[t]{2}{*}{ Institutional ownership $i, t$} & $0.390^{* * *}$ & $0.390^{* * *}$ & $0.390^{* * *}$ & $0.390^{* * *}$ \\
\hline & $(4.58)$ & $(4.59)$ & $(4.59)$ & $(4.60)$ \\
\hline \multirow[t]{2}{*}{ Firm age $i, t$} & $0.007^{*}$ & $0.007^{*}$ & $0.007^{*}$ & $0.007^{*}$ \\
\hline & $(1.68)$ & $(1.68)$ & $(1.78)$ & $(1.77)$ \\
\hline \multirow[t]{2}{*}{ Size $_{i, t}$} & $-0.795^{* * *}$ & $-0.791^{* * *}$ & $-0.776^{* * *}$ & $-0.773^{* * *}$ \\
\hline & $(-35.23)$ & $(-35.96)$ & $(-33.98)$ & $(-34.67)$ \\
\hline \multirow[t]{2}{*}{$R O A_{i, t}$} & $3.204^{* * *}$ & $3.424^{* * *}$ & $3.054^{* * *}$ & $3.264^{* * *}$ \\
\hline & $(8.86)$ & $(9.63)$ & $(8.47)$ & $(9.22)$ \\
\hline \multirow[t]{2}{*}{ Leverage $_{i, t}$} & -0.140 & -0.155 & $-0.678^{* * *}$ & $-0.692^{* * *}$ \\
\hline & $(-1.47)$ & $(-1.64)$ & $(-6.98)$ & $(-7.17)$ \\
\hline \multirow[t]{2}{*}{ Intercept } & $19.364^{* * *}$ & $19.034^{* * *}$ & $18.920^{* * *}$ & $18.611^{* * *}$ \\
\hline & $(38.42)$ & $(39.11)$ & $(37.35)$ & (38.03) \\
\hline Year & Yes & Yes & Yes & Yes \\
\hline Industry & Yes & Yes & Yes & Yes \\
\hline Observations & 9428 & 9428 & 9295 & 9295 \\
\hline Adjusted R-squared & 0.49 & 0.49 & 0.52 & 0.52 \\
\hline
\end{tabular}

Notes. (1) ${ }^{* * * *},{ }^{* *},{ }^{*}$ indicates significance levels at $0.01,0.05$, and 0.10 , respectively, using two tailed tests. (2) We report in parentheses $t$-statistics based on standard errors that are clustered within firm, and are robust to heteroscedasticity. (3) All the continuous variables are winsorized at 1 and 99\%. (4) See Appendix A for variable definitions

the extant literature on the role of returnee talents. We further test the difference between managerial foreign studying experience and working experience on CSR, which enriches the literature. In addition, we extend the research on upper echelons and the determinants of CSR. Previous CSR literature pays much attention to the institutional and organizational level, and they merely link individual executive traits with CSR performance. This is one of the few studies to examine the role of returnee managers on CSR performance. This study also has important 
implications for the government. Starting from the 1990s, the Chinese Central Government and provinces promulgated a series of policies to attract talents with foreign study or work experience. Our study provides empirical evidence that returnee managers promote corporate social responsibility performance. Returnees serve as messengers to transmit better management and corporate practices to enterprises in emerging markets. In this regard, we believe that this study adds interesting and important information to the implementation effect of these policies.

\section{Endnotes}

${ }^{1}$ Hexun.com, founded in 1996, is the first vertical financial portal website in China and quickly excelled in the market of financial and securities information services. Since 2010, Hexun.com has released its CSR evaluation annually.

${ }^{2}$ According to our hand-collected managerial foreign experience data, the most attractive countries for Chinese talents are the United States, the United Kingdom, Japan, Canada, and Australia. Most are developed countries with advanced education systems and economic performance.

${ }^{3}$ Since the 1990s, provincial governments in China began to adopt policies to attract talents with foreign experience back to China, hoping to foster entrepreneurial activity and support the economy. Henan and Anhui provinces were the first to adopt a talent policy and other provinces followed suit from 2000. In December 2008, the Central Government issued a policy titled "High-level Overseas Talent Introduction Plan" (shortened as the "Thousand Talents Plan"), that aims to promote the development of strategic emerging industries and accelerate the transformation of economic development.

${ }^{4}$ Data can be downloaded from http://stockdata.stock.hexun.com/zrbg/

${ }^{5}$ The first CSR report in China was disclosed in 1999. In 2006, the Shenzhen Stock exchange promulgated "Guidelines on Corporate Social Responsibility of Shenzhen Stock Exchange Listed Companies," after which China saw a growth of CSR reports from 23 in 2006 to 77 in 2007. In 2008, the State-owned Assets Supervision and Administration Commission (SASAC) and the Shanghai Stock exchange issued "Guidelines on Corporate Social Responsibility on Central Enterprises" and "Notice on Environmental Information Disclosure Guidelines of Listed Companies of Shanghai Stock Exchange," respectively. Then the number of CSR reports increased from 121 in 2008 to 533 in 2009. In 2014, 681 companies (27.6\% of all listed companies) disclosed CSR reports. However, the disclosure rate is still low.

${ }^{6}$ According to the International Monetary Fund, the following 39 economies are classified as "advanced economies": Australia, Austria, Belgium, Canada, Cyprus, Czech Republic, Denmark, Estonia, Finland, France, Germany, Greece, Hong Kong, Iceland, Ireland, Israel, Italy, Japan, Latvia, Lithuania, Luxembourg, Macau, Malta, Netherlands, New Zealand, Norway, Portugal, Puerto Rico, San Marino, Singapore, Slovakia, Slovenia, South Korea, Spain, Sweden, Switzerland, Taiwan, United Kingdom, and the United States.

${ }^{7}$ The results are available upon request. 


\section{Appendix A}

Table 12 Definition of Main Variables

\begin{tabular}{|c|c|}
\hline Variable Name & Definition \\
\hline \multicolumn{2}{|c|}{ Panel A: Variables of CSR } \\
\hline CSR_Score & $\begin{array}{l}\text { CSR evaluation score released by Hexun.com. The total score is 100, the higher score } \\
\text { represents better performance of CSR. }\end{array}$ \\
\hline CSR_Rate & $\begin{array}{l}\text { CSR evaluation rate released by Hexun.com. We give } 5 \text { scores for } A \text { level (the highest), } \\
\text { and } 1 \text { for E level (the lowest). The rest can be done in the same manner. }\end{array}$ \\
\hline RKS_Score & $\begin{array}{l}\text { CSR evaluation score released by RKS. The higher score represents better CSR } \\
\text { performance. }\end{array}$ \\
\hline RKS_Level & $\begin{array}{l}\text { CSR evaluation rate released by RKS. The higher level represents better CSR } \\
\text { performance. }\end{array}$ \\
\hline \multicolumn{2}{|c|}{ Panel B: Variables of managerial foreign experience } \\
\hline Returnee $(0 / 1)$ & $\begin{array}{l}\text { A dummy variable which equals } 1 \text { if firm } i \text { has at least one returnee manager with } \\
\text { foreign experience in year } t \text { and } 0 \text { otherwise }\end{array}$ \\
\hline Returnee number & Number of returnee managers in year $t$ \\
\hline Returnee work (0/1) & $\begin{array}{l}\text { A dummy variable which equals } 1 \text { if firm } i \text { has at least one returnee manager with } \\
\text { foreign work experience in year } t \text { and } 0 \text { otherwise }\end{array}$ \\
\hline Returnee study(0/1) & $\begin{array}{l}\text { A dummy variable which equals } 1 \text { if firm } i \text { has at least one returnee manager with } \\
\text { foreign study experience in year } t \text { and } 0 \text { otherwise }\end{array}$ \\
\hline $\begin{array}{l}\text { Returnee developed } \\
(0 / 1)\end{array}$ & $\begin{array}{l}\text { A dummy variable which equals } 1 \text { if firm } i \text { has at least one returnee manager obtained } \\
\text { foreign experience from at least one developed economy in year } t \text { and } 0 \text { otherwise }\end{array}$ \\
\hline $\begin{array}{l}\text { Returnee number } \\
\text { developed }\end{array}$ & $\begin{array}{l}\text { Number of returnee managers obtained foreign experience from at least one developed } \\
\text { economy in year } t\end{array}$ \\
\hline \multicolumn{2}{|c|}{ Panel C: Other variables } \\
\hline State control $(0 / 1)$ & A dummy variable which equals 1 if firm is a state-owned entity and 0 otherwise \\
\hline Board independence & The proportion of independent directors in a board in year $t$ \\
\hline Board size & The number of directors in a board in year $t$ \\
\hline Power balance & $\begin{array}{l}\text { The ratio of the number of shares held by the largest shareholder divided by the sum } \\
\text { of the number of shares held by the second to the fifth largest shareholders in year } t\end{array}$ \\
\hline Duality $(0 / 1)$ & A dummy variable equals 1 if chairman and CEO is the same person and 0 otherwise \\
\hline $\begin{array}{l}\text { Managerial } \\
\text { ownership }\end{array}$ & $\begin{array}{l}\text { The number of the shares held by management divided by the total shares in issue in } \\
\text { year } t\end{array}$ \\
\hline $\begin{array}{l}\text { Institutional } \\
\text { ownership }\end{array}$ & $\begin{array}{l}\text { The number of shares held by institutional investors divided by the total shares in issue } \\
\text { in year } t\end{array}$ \\
\hline Firm age & $\begin{array}{l}\text { Firm i's age, which equals to the difference of fiscal year } t \text { minus the year the firm } \\
\text { established }\end{array}$ \\
\hline Size & The natural logarithm of book value of total assets in year $t$ \\
\hline$R O A$ & Return on assets, which equals to net income divided by total assets in year $t$ \\
\hline Leverage & The book value of total debts divided by the book value of total assets \\
\hline Growth & The increased percentage of sales growth in year $t$ \\
\hline Top1 & The proportion of ownership by the largest shareholder \\
\hline DA & $\begin{array}{l}\text { Discretionary accruals, proxy for information asymmetry, calculated by modified Jones } \\
\text { Model }\end{array}$ \\
\hline
\end{tabular}

\section{Acknowledgements}

This paper is supported by the Fundamental Research Funds for the Central Universities, and the Research Funds of Renmin University of China (No. 15XN1010). 


\section{Authors' contributions}

WW carried out data collection, data analyzing and drafted the manuscript. JBS helped to draft the manuscript and provided guidance on the data analysis. Both authors read and approved the final manuscript.

\section{Authors' information}

Wen Wen is a Ph.D candidate in the School of Business at Renmin University of China. Her research interests cover corporate governance and financial accounting. Jianbo Song is a professor in the School of Business at Renmin University of China. Her research interests cover financial accounting and managerial accounting.

\section{Competing interests}

The authors declare that they have no competing interests.

\section{Publisher's Note}

Springer Nature remains neutral with regard to jurisdictional claims in published maps and institutional affiliations.

Received: 21 May 2017 Accepted: 1 September 2017

Published online: 14 September 2017

\section{References}

Aguinis, H., \& Glavas, A. (2012). What We Know and Don't Know about Corporate Social Responsibility: A Review and Research Agenda. Journal of Management, 38(4), 932-968.

Barnea, A., \& Rubin, A. (2010). Corporate Social Responsibility as a Conflict between Shareholders. Journal of Business Ethics, $97(1), 71-86$.

Campbell, J. L. (2007). Why Would Corporations Behave in Socially Responsible Ways? An Institutional Theory of Corporate Social Responsibility. Academy of Management Review, 32(3), 946-967.

Chahal, H., \& Sharma, R. D. (2006). Implications of Corporate Social Responsibility on Marketing Performance: A Conceptual Framework. Journal of Services Research, 6(1), 205-216.

Dhaliwal, S. D., Li, O. Z., Tsang, A., \& Yang, Y. G. (2011). Voluntary Nonfinancial Disclosure and the Cost of Equity Capital: the Initiation of Corporate Social Responsibility Reporting. Social Science Electronic Publishing, 86(1), 59-100.

Dhaliwal, S. D., Radhakrishnan, S., Tsang, A., \& Yang, Y. G. (2012). Nonfinancial Disclosure and Analyst Forecast Accuracy: International Evidence on Corporate Social Responsibility Disclosure. Accounting Review, 87(3), 723-759.

Davis, K. (1973). The Case for and against Business Assumption of Social Responsibilities. Academy of Management Journal, 16(2), 312-322.

Dechow, P. M., Sloan, R. G., \& Sweeney, A. P. (1995). Detecting Earnings Management. Accounting Review, 70(2), 193-225.

Fernandez-Feijoo, B., Romero, S., \& Ruiz, S. (2014). Effect of Stakeholders' Pressure on Transparency of Sustainability Reports within the GRI Framework. Journal of Business Ethics, 122(1), 53-63.

Friedman, M. (1970). The Social Responsibility of Business is to Increase its Profits. New York Times, 13, 122-126

Gao, YQ, Chen YJ, \& Zhang YJ. 高勇强, 陈亚静, 张云均. (2012). “红领巾"还是 “绿领巾”:民营企业慈善捐赠动机研究 ("Red Scarf" or "Green Scarf": A Study on Charity Motivations of Private Enterprises). 管理世界(Management World), (8): 106-114.

Ghoul, S. E., Guedhami, O., Kwok, C. C. Y., \& Mishra, D. R. (2011). Does Corporate Social Responsibility Affect the Cost of Capital? Journal of Banking \& Finance, 35(9), 2388-2406.

Giannetti, M., Liao, G., \& Yu, X. (2015). The Brain Gain of Corporate Boards: Evidence from China. The Journal of Finance, 70(4), 1629-1682

Goss, A., \& Roberts, G. S. (2011). The Impact of Corporate Social Responsibility on the Cost of Bank Loans. Journal of Banking \& Finance, 35(7), 1794-1810.

Greening, D. W., \& Gray, B. (1994). Testing a Model of Organizational Response to Social and Political Issues. Academy of Management Journal, 37(3), 467-498.

Hambrick, D. C., \& Mason, P. A. (1984). Upper Echelons: The Organization as A Reflection of Its Top Managers. Academy of Management Review, 9(2), 193-206.

Han, J, Tian GL, \& Li LC. 韩洁, 田高良, 李留闯. (2012). 连锁董事与社会责任报告披露——基于组织间模仿的视 角(Interlocking Directors and Social Responsibility Disclosure: from the Perspective of Inter-organizational Imitation).管理科学(Journal of Management Science), (8): 106-114.

Haniffa, R M, \& Cooke, T. E. 2005. The Impact of Culture and Governance on Corporate Social Reporting. Journal of Accounting and Public Policy, 24 (5): 391-430.

Harjoto, M. A., \& Jo, H. (2011). Corporate Governance and CSR Nexus. Journal of Business Ethics, 100(1), 45-67.

Heckman, J. J. (1979). Sample Selection Bias As a Specification Error. Econometrica, 47, 153-161.

Jia, XP, \& Liu Y. 贾兴平, 刘益. (2014). 外部环境,内部资源与企业社会责任(External Environment, Internal Resources and Corporate Social Responsibility.) 南开管理评论(Naikai Business Review), (6): 13-18.

Kennedy, P. (1988). A Guide to Econometrics (4th ed.). Oxford: Blackwell Publishing.

Khan, A., Muttakin, M. B., \& Siddiqui, J. (2013). Corporate Governance and Corporate Social Responsibility Disclosures: Evidence from an Emerging Economy. Journal of Business Ethics, 114(2), 207-223.

Lawrence, A., Minutti-Meza, M., \& Zhang, P. (2011). Can Big 4 Versus Non-big 4 Differences in Audit-quality Proxies be Attributed to Client Characteristics? Accounting Review, 86(1), 259-286.

McWilliams, A., \& Siegel, D. (2001). Corporate Social Responsibility: A Theory of the Firm Perspective. Academy of Management Review, 26(1), 117-127.

Miletkov, M., Poulsen, A., \& Wintoki, M. B. (2017). Foreign Independent Directors and the Quality of Legal Institutions. Journal of International Business Studies, 48(2), 1-26. 
Muller, A., \& Kolk, A. (2010). Extrinsic and Intrinsic Drivers of Corporate Social Performance: Evidence from Foreign and Domestic Firms in Mexico. Journal of Management Studies, 47(1), 1-26.

Oh, W. Y., Chang, Y. K., \& Martynov, A. (2011). The Effect of Ownership Structure on Corporate Social Responsibility: Empirical Evidence from Korea. Journal of Business Ethics, 104(2), 283-297.

Oikonomou, l., Brooks, C., \& Pavelin, S. (2014). The Effects of Corporate Social Performance on the Cost of Corporate Debt and Credit Ratings. Financial Review, 49(1), 49-75.

Peloza, J. (2006). Using Corporate Social Responsibility as Insurance for Financial Performance. California Management Review, 48(2), 52-72.

Quan, XF, Wu SN, \& Yin HY. 权小锋, 吴世农, 尹洪英. (2015). 企业社会责任与股价崩盘风险: “价值利器”或”自利工 具"?(Corporate Social Responsibility and Stock Price Crash Risk: "Self-interest Tool" or "Value Strategy"?) 经济研 究(Economic Research Journal), (11): 49-64.

Ramus, C. A., \& Steger, U. (2000). The Roles of Supervisory Support Behaviors and Environmental Policy in Employee "Ecoinitiatives" at Leading-edge European Companies. Academy of Management Journal, 43(4), 605-626.

Roberts, R. W. (2004). Determinants of Corporate Social Responsibility Disclosure: An Application of Stakeholder Theory. Accounting, Organizations and Society, 17(6), 595-612.

Waddock, S. A., \& Graves, S. B. (2015). The Corporate Social Performance-financial Performance Link. Strategic Management Journal, 18(4), 303-319.

Walsh, G., \& Beatty, S. E. (2007). Customer-based Corporate Reputation of a Service Firm: Scale Development and Validation. Journal of the Academy of Marketing Science, 35(1), 127-143.

Wang, HC, Cao F, \& Ye KT. 王化成, 曹丰, 叶康涛. (2015). 监督还是掏空: 大股东持股比例与股价崩盘风险 (Monitoring or Tunneling: Controlling Shareholders and Stock Price Crash Risk). 管理世界(Management World), (2): 45-57.

Wang, HM, Lv XJ, \& Lin WF. 王海妹, 吕晓静, 林晚发. (2014). 外资参股和高管,机构持股对企业社会责任的影 响——基于中国A股上市公司的实证研究(The Effect of Foreign Equity Participation, Executive Ownership， Institutional Ownership on Corporate Social Responsibility_-Based on the Empirical Test of A-share Public Companies in China). 会计研究(The Accounting Research), (8): 81-87.

Wang, WL, Jiao J, Jin ZM, \& Zhu B. 王文龙,焦捷,金占明,朱斌. (2015). 企业主宗教信仰与企业慈善捐赠(CEO's Religious Belief and Corporate Philanthropic Giving). 清华大学学报(自然科学版) (Journal of Tsinghua University (Science and Technological)), (4): 443-451.

Weaver, G. R., Trevino, L. K., \& Cochran, P. L. (1999a). Integrated and Decoupled Corporate Social Performance: Management Commitments, External Pressures, and Corporate ethics Practices. Academy of Management Journal, 42(5), 539-552.

Weaver, G. R., Trevino, L. K., \& Cochran, P. L. (1999b). Corporate Ethics Programs as Control Systems: Influences of Executive Commitment and Environmental Factors. Academy of Management Journal, 42(1), 41-57.

Yi, KG. 易开刚. (2011). 企业社会责任的多重价值博亦与长效实现机制——基于公司治理的视角 (Study on the multiple values game and long-term mechanism of corporate social responsibility ——A perspective of corporate governance). 经济理论与经济管理(Economic Theory and Business Management), (12): 61-67.

Zweig, D. (2006). Competing for Talent: China's Strategies to Reverse the Brain Drain. International Labor Review, $145(1-2), 65-89$.

\section{Submit your manuscript to a SpringerOpen ${ }^{\circ}$ journal and benefit from:}

- Convenient online submission

- Rigorous peer review

- Open access: articles freely available online

- High visibility within the field

- Retaining the copyright to your article 